\title{
SIZE OF BANKS AS A FACTOR WHICH IMPACTS THE EFFICIENCY OF THE BANK LENDING CHANNEL
}

\author{
Filip ŚWITAŁA ${ }^{1}$, IWONA KoWALSKA ${ }^{2}$, KAROLINA MALAJKAT ${ }^{3}$
}

Abstract

\begin{abstract}
In most economies the banking sector plays the major role in the financial system. Therefore, it is of great importance to analyse and understand the mechanism of transmission of monetary policy and its impact on the banking sector. One of the possible repercussions of changing the level of official interest rates is the ability to influence the size of bank lending, by means of the bank lending channel. The key aspect our research is a thorough understanding of the functioning of the bank lending channel, with the main goal of this study being an examination of the efficiency of monetary policy transmission through the bank lending channel depending on the size of banks in the sector. This paper examines the abovementioned relation using annual data from 1995-2015 by 1709 commercial and cooperative banks from $27 \mathrm{EU}$ countries and analyzing them in various econometric models. The results indicate that there is a positive impact of a bank's size on loan growth (defined as the bank size increases, the impact of changes in interest rates in the bank's lending policy is getting smaller), however, interaction between the variables of size and the interest rate, was proved to be insignificant (in the group of all analysed banks, as well as in commercial and cooperative banks separately).
\end{abstract}

\footnotetext{
${ }^{1}$ Faculty of Management, University of Warsaw, Poland, ORCID: 0000-0002-8046-5240.

${ }^{2}$ Faculty of Management, University of Warsaw, Poland, ORCID: 0000-0002-1208-2790

${ }^{3}$ Corresponding author, Collegium of Socio-Economics, Warsaw School of Economics, Poland, e-mail: kmwojcicka@gmail.com.
} 


\section{INTRODUCTION}

Without a doubt it is crucial to understand the mechanisms behind transmission of monetary policy into the real economy. Assuming that banks play a key role in most financial systems, inter alia through granting access to means of financing of enterprises and households, which have limited access to other financing sources, it is worth underlining that potential decline in loan granting by banks may have a direct impact on the functioning of these entities and economy as a whole. Therefore, it is of great importance to understand the mechanism which may potentially influence the effectiveness of the bank lending channel, which accentuates the impact of monetary policy changes on the volume of loans granted by the domestic banking sector (changes in supply).

The main goal of this paper is to verify the hypotheses about the impact of the bank's size on changes in the volume of loans -- and the effectiveness of the monetary policy transmission mechanism through the bank lending channel.The study was carried out on the basis of an analysis of literature and quantitative research, based on econometric models.

To reach the aim of the article and answer the question of whether the size of banks in the sector influences the effectiveness of the bank lending channel, the study is divided into three main sections. Section 2 provides theoretical and empirical literature on the functioning of the bank lending channel depending on the sizes of banks. It is generally argued that following a monetary tightening, smaller banks are less likely to supply loans, however this section also provides contradicting conclusions. Section 3 discusses the empirical methodology, data sources and the variables used in the study whereas Section 4 presents and discusses obtained results.

\section{LITERATURE REVIEW}

The issue of the functioning of the bank lending channel and its effectiveness has been of interest to many scientists, economists, regulators and banking professionals. However, beyond sole testing of the existence of the bank lending channel, several empirical approaches have been used to investigate the functioning and strength of the bank lending channel, especially in the context of characteristics of the banking sector. One of the factors which is taken into account by many researchers is the size of banks in the sector and its impact on the strength of the bank lending channel.

It is generally argued that following a monetary tightening, smaller banks are less likely to supply loans. Kashyap and Stein (1995) illustrated that when the Fed drains deposits from the system, banks cannot frictionlessly make up the funding shortfall by raising non-deposit external finance. Consequently, their lending behaviour is affected, and so in turn is the investment spending of those non-financial firms that rely on banks for funding. In their research, based on disaggregated US data, they constructed bank groups by size and looked at how deposits, securities and loans of these groups responded to monetary policy shocks. Researchers argued that if the abovementioned lending view of monetary policy transmission is correct, one should expect the loan and security portfolios of large and small banks to respond differentially to a contraction in monetary policy. They suggested that if banks are hit by the same deposit and loan demand shocks, then small banks will cut their loan supply more rapidly since they find it costlier to make up for a monetary policy induced shortfall in funds. They also emphasized that liquidity constraints usually become more pronounced for small banks.

De Santis and Surico (2013) also contribute to the literature by investigating availability of credit depending on monetary policy with regard to bank characteristics in the four largest economies of the euro area. Their results indicated that changes in the cost of funding engineered by monetary policy actions exert their maximum impact on cooperative and saving banks in Germany, especially those with lesser liquidity and lower capital, and saving banks in Italy, especially those with smaller size. At the same time large commercial banks appear more capable of isolating their lending activities from changes in monetary policy conditions. According to their findings, an increase in the number of smaller banks: cooperative and savings banks, is likely to improve the transmission mechanism of monetary policy in the euro area.

Similar results of research confirming that size of the bank determines the strength of the bank lending channel, with small banks reacting more actively and therefore enhancing the transmission mechanism of monetary policy, were also obtained by De Haan (2001), Meral (2015), Matousek and Sarantis (2009).

On the other hand, when Ananchotikul and 
Seneviratne (2015) also tried to tackle the question of "How do banks' characteristics affect the effectiveness of monetary policy transmission?", they came up with a contradicting conclusion. In their paper both authors examined the effectiveness of monetary policy transmission in selected Asian countries. In the course of research, the authors compared the measure of monetary policy with bank size based on bank assets, capitalization, liquidity, and the loan-to-deposit ratio. Their results are that interaction terms on capitalization are only weakly significant (mainly due to the fact that capital ratios of most Asian banks are well above regulatory floors) and that less liquid banks and/or banks with higher LDRs are found to respond more strongly to domestic monetary policy shocks. At the same time the authors did not find bank size to be an important factor determining the credit supply response to monetary policy changes as the coefficients on the interaction terms between bank size and monetary policy were not statistically different from the baseline effect.

A contradicting result was also obtained by Havrylchyk and Jurzyk (2005) who investigated the role of banks in the transmission of monetary policy in Poland. They argued that, based on the results, after a tightening of monetary policy big banks contract credit more than small banks. Even though the result seemed to be counterintuitive, both authors explained it based on the specific situation of the Polish banking sector during the examined period (1997-2002). Big banks were faced with a growing bad loan problem therefore they contracted their lending to both firms and private customers investing in Treasury Bonds (which yield higher returns) instead. Small banks (many of which were start-ups) were, on the other hand, free of a bad loan problem, had access to better credit rating procedures and expanded lending trying to acquire market share.

\section{RESEARCH METHODOLOGY}

To verify the hypotheses about the impact of bank size on changes in the volume of loans - and the effectiveness of the monetary policy transmission mechanism through the bank lending channel - the following model was used:

$$
\begin{gathered}
\Delta \log (\text { Loan })_{\mathrm{i}, \mathrm{t}}=\alpha_{1} \Delta \log (\text { Loan })_{\mathrm{i}, \mathrm{t}-1}+\alpha_{2} \mathrm{GDPG}_{\mathrm{j}, \mathrm{t}-1}+\alpha_{3} \Delta \mathrm{IR}_{\mathrm{j}, \mathrm{t}-1}+ \\
+\alpha_{4} \Delta \log \left(\text { Equity }_{\mathrm{i}, \mathrm{t}}+\alpha_{5} \Delta \log (\text { LiquidAssets })_{\mathrm{i}, \mathrm{t}}+\alpha_{6} \text { Size }_{\mathrm{i}, \mathrm{t}}+\right. \\
+\alpha_{7} \operatorname{Size}_{i, \mathrm{t}} \cdot \Delta \mathrm{IR}_{\mathrm{j}, \mathrm{t}-1_{\mathrm{i}, \mathrm{t}}}+\vartheta_{\mathrm{i}, \mathrm{t}}+\varepsilon_{\mathrm{t}}
\end{gathered}
$$

where:

$$
\text { - } \Delta \log (\text { Loan })_{i, t}-\text { logarithm of total loans of bank } i
$$
at time $\mathrm{t}$

- $G D P G_{t}$ - real GDP growth in country $\mathrm{j}$ at time $\mathrm{t}$ to control the demand-side that affects bank loans; $\mathrm{j}$ at time t;

$$
\text { - } \Delta I R_{j, t} \text { - annual change in interest rate in country }
$$

$$
\text { - } \Delta \log \text { Equity }_{i, t} \text { - logarithm of equity of bank i at }
$$
time t;

- $\Delta \log$ (LiquidAssets) $_{i, t}$ - logarithm of non-earning assets of bank $\mathrm{i}$ at time $\mathrm{t}$, where non-earning assets in Bankscope are defined as: cash, non-interest-bearing interbank deposits, intangible and other non-earning assets;

- Size $_{i, t}$ - size of bank $\mathrm{i}$ at time $\mathrm{t}$ - in the analysis defined - in two ways - 1) as logarithm of total assets 2) as a standardized variable i.e. deviations from their cross-sectional means as follows (like in Ehrmann et al.; 2003 and Topi and Vilmunen; 2001):

$$
\begin{aligned}
& \text { size }_{i, \mathrm{t}}=\operatorname{size}_{i, \mathrm{t}-1}-\frac{1}{N} \sum_{j=1}^{N} x_{j, t} \\
& -\operatorname{Size}_{i, t} \cdot \Delta I R_{j, t-1}-\text { interaction between Size and }
\end{aligned}
$$
Interest Rate (IR) was added to the model in order to investigate the effect of changes in IR depending on the size of the bank;

- $\theta_{i, t}$ are unobservable bank-specific effects that are not constant over time but vary across banks; $\varepsilon_{t}$ is a white-noise error term.

As the measure of 'interest rate', 'money interest rate' was adopted - i.e. rates at which short-term loans are made between financial institutions - usually defined as average daily rates in percentages. Where possible, short-term interest rates were based on three-month money market rates. It is worth mentioning that longterm interest rates were also verified. In this case the interest rate on government bonds with a maturity of 10 years - usually average daily rates measured as a percentage - was assumed to be the level of long-term interest rates. These rates are implied by prices at which government bonds are traded on financial markets and relate to bonds whose repayment of capital is guaranteed by governments. The basic interest rate of central banks the discount interest rate -is the interest rate at which the central bank lends funds to commercial banks.

The model takes into account the interaction between the variable Interest Rate and Size to verify that the size 
of the bank is of particular importance, or, if, in a way, it strengthens the impact of interest rate changes. To this end, the Size variable has been defined in two ways (as described above). A positive sign with this variable would indicate that as the bank size increases, the impact of changes in interest rates in the bank's lending policy is getting smaller (there is a weakening effect) while a negative sign would indicate that interest rate increase is particularly important in banks with larger assets. Nevertheless, the nature of a bank - commercial or cooperative - may be the key factor in this area - it may be an important factor differentiating reactions. If banks are affected by the same demand shock on loans, small banks may reduce the supply of loans due to the costgenerating need to replenish their own funds. A stronger reaction of small banks should also be observed due to potential restrictions on their liquidity. Therefore, along with the basic model, models for the group of commercial and cooperative banks were estimated.
The research was based on data from banks from 27 EU countries that were obtained from the Bankscope from the Bureau van Dijk database (a comprehensive banking database used to analyze and monitor the economic and financial standing of banks and other financial institutions), as well as macroeconomic data from: the International Monetary Fund (IMF), International Financial Statistics (IFS), European Central Bank (ECB), World Bank and even data from central banks to fill data gaps.

The database on which the survey was conducted covered annual data from 1995-2015 by 1709 commercial and cooperative banks, as it was limited to banks for which there was a minimum of 5 consecutive values of the dependent variable (delta credits).

The basic characteristics of the values used and the correlations between them are presented below in Table 1.

Table 1: Descriptive statistics

\begin{tabular}{|c|c|c|c|c|c|c|c|c|c|c|c|c|c|c|c|}
\hline \multirow{2}{*}{ Variable } & \multicolumn{5}{|c|}{ full sample } & \multicolumn{5}{|c|}{ commercial banks } & \multicolumn{5}{|c|}{ cooperative banks } \\
\hline & Obs & Mean & St.D. & Min & $\operatorname{Max}$ & Obs & Mean & St.D. & Min & $\operatorname{Max}$ & Obs & Mean & St.D. & Min & Max \\
\hline$\Delta \log$ (loans) & 25735 & 0.07 & 0.34 & -7.23 & 9.81 & 11067 & 0.10 & 0.50 & -7.23 & 9.81 & 14668 & 0.04 & 0.14 & -0.95 & 1.23 \\
\hline GDPG & 32813 & 1.70 & 2.41 & -14.81 & 12.49 & 14706 & 2.03 & 2.75 & -14.81 & 12.49 & 18107 & 1.44 & 2.07 & -5.62 & 4.08 \\
\hline$\Delta \mathrm{IR}$ & 28365 & -0.42 & 2.92 & -63.95 & 66.80 & 10258 & -0.63 & 4.81 & -63.95 & 66.80 & 18107 & -0.30 & 0.49 & -1.11 & 0.77 \\
\hline$\Delta \log ($ Equity) & 25811 & 0.08 & 0.24 & -6.14 & 5.97 & 11143 & 0.09 & 0.32 & -6.14 & 5.97 & 14668 & 0.08 & 0.15 & -0.95 & 1.54 \\
\hline$\Delta \log ($ LiqAssets) & 25809 & 0.06 & 0.51 & -8.20 & 9.88 & 11145 & 0.10 & 0.69 & -8.20 & 9.88 & 14664 & 0.03 & 0.30 & -2.47 & 2.64 \\
\hline $\log$ (Assets) & 28015 & 13.46 & 1.82 & 3.65 & 21.86 & 12129 & 14.23 & 2.21 & 3.65 & 21.86 & 15886 & 12.88 & 1.14 & 7.77 & 19.76 \\
\hline Size' & 28015 & 0.00 & 1.79 & -10.10 & 8.21 & 12129 & 0.00 & 2.17 & -10.10 & 8.21 & 15886 & 0.00 & 1.12 & -5.54 & 6.16 \\
\hline
\end{tabular}

Table 2: Correlation matrix

\begin{tabular}{|c|c|c|c|c|c|c|c|c|}
\hline \multicolumn{9}{|c|}{ full sample } \\
\hline & $\Delta \log (\text { loans })_{\mathrm{t}}$ & $\Delta \log (\text { loans })_{\mathrm{t}-1}$ & $\mathrm{GDPG}_{\mathrm{t}-1}$ & $\Delta I R_{t-1}$ & $\Delta \log (\text { Equity })_{\mathrm{t}}$ & $\Delta \log (\text { LiqAss })_{t}$ & $\log (\text { Assets })_{t}$ & Size $_{t}^{\prime}$ \\
\hline$\Delta \log (\text { loans })_{\mathrm{t}}$ & 1 & & & & & & & \\
\hline$\Delta \log (\text { loans })_{\mathrm{t}-1}$ & $0.034 * * *$ & 1 & & & & & & \\
\hline $\mathrm{GDPG}_{\mathrm{t}-1}$ & $0.122^{* * *}$ & $0.075^{* * *}$ & 1 & & & & & \\
\hline$\Delta I R_{t-1}$ & $-0.04 * * *$ & $-0.04 * * *$ & -0.00 & 1 & & & & \\
\hline$\Delta \log (\text { Equity })_{t}$ & $0.395^{* * *}$ & $0.091^{* * *}$ & $0.119 * * *$ & $-0.05^{* * *}$ & 1 & & & \\
\hline$\Delta \log (\text { LiqAssets })_{t}$ & $0.211^{* * *}$ & $0.056 * * *$ & $0.075^{* * *}$ & $-0.04 * * *$ & $0.258^{* * *}$ & 1 & & \\
\hline $\log (\text { Assets })_{t}$ & $0.031^{* * *}$ & $0.054 * * *$ & $-0.02 * * *$ & $0.016 * *$ & $0.05^{* * *}$ & $0.026 * * *$ & 1 & \\
\hline Size' $_{t}$ & $0.033^{* * *}$ & $0.048^{* * *}$ & $0.014^{* *}$ & 0.009 & $0.043^{* * *}$ & $0.035^{* * *}$ & $0.985^{* * *}$ & 1 \\
\hline \multicolumn{9}{|c|}{ commercial banks } \\
\hline & $\Delta \log (\text { loans })_{\mathrm{t}}$ & $\Delta \log (\text { loans })_{\mathrm{t}-1}$ & $\mathrm{GDPG}_{\mathrm{t}-1}$ & $\Delta I R_{t-1}$ & $\Delta \log (\text { Equity })_{\mathrm{t}}$ & $\Delta \log (\text { LiqAss })_{t}$ & $\log (\text { Assets })_{t}$ & Size $_{t}^{\prime}$ \\
\hline$\Delta \log (\text { loans })_{\mathrm{t}}$ & 1 & & & & & & & \\
\hline 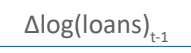 & $0.032 * * *$ & 1 & & & & & & \\
\hline $\mathrm{GDPG}_{\mathrm{t}-1}$ & $0.131 * * *$ & $0.122 * * *$ & 1 & & & & & \\
\hline$\Delta I R_{t-1}$ & $-0.03^{* * *}$ & $-0.04 * * *$ & $-0.05^{* * *}$ & 1 & & & & \\
\hline
\end{tabular}




\begin{tabular}{|c|c|c|c|c|c|c|c|c|}
\hline$\Delta \log (\text { Equity })_{t}$ & $0.315^{* * *}$ & $0.124 * * *$ & $0.136 * * *$ & $-0.05 * * *$ & 1 & & & \\
\hline$\Delta \log (\text { LiqAssets })_{t}$ & $0.174 * * *$ & $0.065 * * *$ & $0.084 * * *$ & $-0.04 * * *$ & $0.222 * * *$ & 1 & & \\
\hline $\log (\text { Assets })_{t}$ & $-0.01 * *$ & 0.004 & $-0.08 * * *$ & $0.056^{* * *}$ & $0.031^{* * *}$ & -0.00 & 1 & \\
\hline Size $_{t}^{\prime}$ & -0.01 & 0.003 & $-0.04 * * *$ & $0.047 * * *$ & $0.033^{* * *}$ & 0.001 & $0.990 * * *$ & 1 \\
\hline \multicolumn{9}{|c|}{ cooperative banks } \\
\hline & $\Delta \log (\text { loans })_{\mathrm{t}}$ & $\Delta \log {\text { (loans })_{t-1}}$ & $\mathrm{GDPG}_{\mathrm{t}-1}$ & $\Delta \mathrm{IR}_{\mathrm{t}-1}$ & $\Delta \log (\text { Equity })_{t}$ & $\Delta \log (\text { LiqAss })_{t}$ & $\log \left(\right.$ Assets) ${ }_{\mathrm{t}}$ & Size $_{t}^{\prime}$ \\
\hline$\Delta \log (\text { loans })_{\mathrm{t}}$ & 1 & & & & & & & \\
\hline$\Delta \log$ (loans) $_{\mathrm{t}-1}$ & $-0.01 *$ & 1 & & & & & & \\
\hline $\mathrm{GDPG}_{\mathrm{t}-1}$ & $0.106 * * *$ & $-0.09 * * *$ & 1 & & & & & \\
\hline$\Delta I R_{t-1}$ & $-0.07 * * *$ & $0.107^{* * *}$ & $0.465 * * *$ & 1 & & & & \\
\hline$\Delta \log (\text { Equity })_{\mathrm{t}}$ & $0.867 * * *$ & $-0.07 * * *$ & $0.089 * * *$ & $-0.11^{* * *}$ & 1 & & & \\
\hline$\Delta \log (\text { LiqAssets })_{t}$ & $0.413^{* * *}$ & $-0.03 * * *$ & $0.045^{* * *}$ & -0.00 & $0.389 * * *$ & 1 & & \\
\hline $\log \left(\right.$ Assets) ${ }_{t}$ & $0.080 * * *$ & $0.092 * * *$ & $-0.03 * * *$ & $-0.02 * * *$ & $0.100 * * *$ & -0.00 & 1 & \\
\hline Size $_{t}^{\prime}$ & $0.058^{* * *}$ & $0.048 * * *$ & 0.005 & -0.00 & $0.061^{* * *}$ & $0.034 * * *$ & $0.963 * * *$ & 1 \\
\hline
\end{tabular}

Correlation relations and descriptive statistics clearly indicate differences between commercial and cooperative banks - for example, a close correlation of bank size with loan dynamics in commercial banks, and slightly lower ratios for the relationship between changes in loans and variables: interest rate, equity and liquid assets.

\section{RESULTS}

In this study we adopt the system of generalized method of moments (GMM) developed by Blundell and Bond (1998) with robust standard errors and Windmejer's correction which corrects for biases introduced by endogeneity problems. The potential endogenity is determined in the two-step system GMM estimation procedure, by the inclusion of up to four lags of explanatory variables as instruments. All regressions include also one lag of a dependent variable to allow for natural convergence (as in Claessens et al., 2013). As a robustness check we estimated fixed effects (FE) and ordinary least squares (OLS) models -the robustness test results will be presented in the final part of the article. The basic model that has been used is a dynamic panel model, to which the GMM according to Blundell and Bond was used.

The model below shows the significance of the size variable added to the model explaining the change in the volume of loans - in this model (2) size was defined as logarithm of assets. As expected, we have a positive impact of the bank's size on loan growth. In addition, one should note a positive - in line with expectations coefficient at GDPG (demand element) - GDP growth by 1 percent (or GDPG by 1p.p.) may cause approx. $0.4 \%$ growth in credit (GDPG in the model expressed in pp). On the other hand, the coefficient at the change of interest rates has a negative sign, i.e. an increase in interest rates limits the banks' lending action - 1 p.p. increase in interest translates into a drop of approx. $0.7 \%$ credit dynamics (IR in the model expressed in p.p.). The increase in own funds translates into an increase in lending, just as higher liquid assets allow an increase in the volume of loans (1\% increase in equity means an increase in loan growth by $0.68 \%$, and an increase in assets by $1 \%$ means an increase in the volume of loans by $0.06 \%$ ).

The most important question, however, concerns the interaction between the variables size and the interest rate. This study was carried out in the model (3) using the variable log(assets) to express the bank size (log (assets)*interest rate was added to the model) and model (4) where the variable size expresses the absolute difference to the average bank size (size').

The conclusions from both models are consistent the interaction is irrelevant, although the size of the bank was positively correlated with the explanatory variable (however, it was a very weak relationship - the correlation coefficient amounted only to 0.03).

When assessing the quality of the estimated GMM models based on the Arellano-Bond autocorrelation test, the null hypothesis about the second order autocorrelation of the random component in the model of the first differences should be rejected-in the constructed models, the autocorrelation does not occur. The occurrence of first order autocorrelation in this model is an expected phenomenon, because if $\theta_{i, t}$ are independent, their first differences are correlated to the first order. In addition, 
Table 3: Full sample results

\begin{tabular}{|c|c|c|c|c|}
\hline \multirow{2}{*}{$\begin{array}{c}\text { Dependent variable: } \\
\Delta \log (\text { loans })_{t}\end{array}$} & \multicolumn{4}{|c|}{ full sample GMM, lag(1 4) } \\
\hline & 1 & 2 & 3 & 4 \\
\hline$\Delta \log (\text { loans })_{\mathrm{t}-1}$ & $\begin{array}{c}0.077 * * * \\
(3.20)\end{array}$ & $\begin{array}{c}0.088 * * * \\
(3.62)\end{array}$ & $\begin{array}{c}0.083^{* * *} \\
(3.61)\end{array}$ & $\begin{array}{c}0.088 * * * \\
(3.63)\end{array}$ \\
\hline GDPG $_{t-1}$ & $\begin{array}{l}0.004^{* * *} \\
(4.20)\end{array}$ & $\begin{array}{c}0.004^{* * *} \\
(4.38)\end{array}$ & $\begin{array}{c}0.003 * * \\
(2.55)\end{array}$ & $\begin{array}{c}0.004 * * * \\
(3.56)\end{array}$ \\
\hline$\Delta I R_{t-1}$ & $\begin{array}{c}-0.007^{*} \\
(-1.79)\end{array}$ & $\begin{array}{c}-0.008^{* *} \\
(-2.04)\end{array}$ & $\begin{array}{l}-0.042 \\
(-0.72)\end{array}$ & $\begin{array}{c}-0.009 * * \\
(-1.97)\end{array}$ \\
\hline$\Delta \log (\text { Equity })_{t}$ & $\begin{array}{c}0.682 * * * \\
(17.53)\end{array}$ & $\begin{array}{c}0.689 * * * \\
(18.82)\end{array}$ & $\begin{array}{c}0.691 * * * \\
(18.62)\end{array}$ & $\begin{array}{l}0.69 * * * \\
(17.78)\end{array}$ \\
\hline$\Delta \log (\text { LiqAssets) })_{\mathrm{t}}$ & $\begin{array}{c}0.058^{* * *} \\
(6.62)\end{array}$ & $\begin{array}{c}0.058^{* * * *} \\
(6.88)\end{array}$ & $\begin{array}{c}0.058^{* * *} \\
(6.74)\end{array}$ & $\begin{array}{c}0.058 * * * \\
(6.59)\end{array}$ \\
\hline Size $_{t}$ & & $\begin{array}{c}0.021^{* *} \\
(2.01)\end{array}$ & $\begin{array}{c}0.022^{* *} \\
(1.97)\end{array}$ & $\begin{array}{l}-0.001 \\
(-0.08)\end{array}$ \\
\hline Size $_{t} \cdot \Delta I R_{t-1}$ & & & $\begin{array}{l}0.003 \\
(0.60)\end{array}$ & $\begin{array}{l}0.005 \\
(1.24)\end{array}$ \\
\hline cons & $\begin{array}{c}-0.013 * * * \\
(-2.96)\end{array}$ & $\begin{array}{c}-0.297^{* *} \\
(-2.11)\end{array}$ & $\begin{array}{c}-0.308^{* *} \\
(-2.06)\end{array}$ & $\begin{array}{c}-0.014 * * * \\
(-3.24)\end{array}$ \\
\hline $\operatorname{AR}(1)$ & -7.47 & -7.49 & -7.56 & -7.49 \\
\hline p-val & 0.00 & 0.00 & 0.00 & 0.00 \\
\hline$A R(2)$ & -0.95 & -0.85 & -0.87 & -0.84 \\
\hline p-val & 0.35 & 0.39 & 0.39 & 0.40 \\
\hline No of observation & 19876 & 19876 & 19876 & 19876 \\
\hline No of banks & 1581 & 1581 & 1581 & 1581 \\
\hline No of instruments & 171 & 171 & 171 & 171 \\
\hline
\end{tabular}

the number of instruments is significantly lower than the number of groups, i.e. banks.

The estimation of analogical models separately in the group of commercial and cooperative banks leads to the following conclusions:

Coefficient at GDPG in all models - both for commercial and cooperative banks is positive - but for cooperative banks much lower - for commercial $0.9 \%$ and for cooperative $0.1 \%$ with $1 \%$ change in GDP dynamics;

The relation between interest rate change and loan dynamics is surprising - in the case of commercial banks the results are not fully unambiguous - there is no significant dependence in the models (5) and (6) and weak dependence in the model (7) (significance at the $10 \%$ significance level). On the other hand, in the case of cooperative banks, another surprising relationship was obtained - requiring further research - in the model (10) we have an insignificant factor, i.e. the change in the interest rate is not relevant from the perspective of changes in the volume of loans granted. In models (8) and (9), the variable was significant, but with a positive sign (maybe due to the lack of other variables in the model of variation-specific variability of loans in the group of cooperative banks), which can be demonstrated by the AR test (2) at the border acceptability, it was decided to estimate identical models in subgroups of banks, so as not to distort the comparison;

Change in equity is more important in cooperative banks than in commercial banks ( $0.83 \%$ vs. $0.45 \%)$;

Significant liquidity in both cases - or what change in liquid assets by $1 \%$ causes a slightly stronger reaction of the volume of loans in commercial banks;

The absolute value of assets in commercial banks is irrelevant and the significance of this variable in corporate banks requires further verification;

And most importantly: the interaction of the size * interest rate in both groups of banks is statistically insignificant.

The results of the models are presented below: 
Table 4: Subsamples - commercial and cooperative banks - results

\begin{tabular}{|c|c|c|c|c|c|c|}
\hline \multirow{3}{*}{$\begin{array}{l}\text { Dependent } \\
\text { variable: } \\
\Delta \log (\text { loans) }\end{array}$} & \multicolumn{6}{|c|}{ GMM, lag(1 4) } \\
\hline & \multicolumn{3}{|c|}{ commercial banks } & \multicolumn{3}{|c|}{ cooperative banks } \\
\hline & 5 & 6 & 7 & 8 & 9 & 10 \\
\hline$\Delta \log (\text { loans) })_{t-1}$ & $\begin{array}{c}0.127^{* *} \\
(2.36)\end{array}$ & $\begin{array}{c}0.136^{* *} \\
(2.42)\end{array}$ & $\begin{array}{c}0.169 * * * \\
(2.94)\end{array}$ & $\begin{array}{c}0.016^{* *} \\
(2.41)\end{array}$ & $\begin{array}{c}0.018^{* * *} \\
(2.69)\end{array}$ & $\begin{array}{c}0.016^{* *} \\
(2.40)\end{array}$ \\
\hline $\mathrm{GDPG}_{\mathrm{t}-1}$ & $\begin{array}{c}0.009 * * \\
(2.51)\end{array}$ & $\begin{array}{c}0.009 * * * \\
(2.68)\end{array}$ & $\begin{array}{l}0.01^{*} \\
(1.67)\end{array}$ & $\begin{array}{c}0.001^{* *} \\
(2.34)\end{array}$ & $\begin{array}{c}0.001^{* *} \\
(2.23)\end{array}$ & $\begin{array}{c}0.001^{* * *} \\
(4.16)\end{array}$ \\
\hline$\Delta I R_{t-1}$ & $\begin{array}{l}-0.011 \\
(-1.52)\end{array}$ & $\begin{array}{l}-0.012 \\
(-1.54)\end{array}$ & $\begin{array}{c}-0.017^{*} \\
(-1.67)\end{array}$ & $\begin{array}{c}0.005^{* *} \\
(2.24)\end{array}$ & $\begin{array}{c}0.004^{* *} \\
(2.08)\end{array}$ & $\begin{array}{l}0.001 \\
(0.55)\end{array}$ \\
\hline$\Delta \log (\text { Equity })_{t}$ & $\begin{array}{c}0.454^{* * *} \\
(6.26)\end{array}$ & $\begin{array}{c}0.454^{* * *} \\
(6.52)\end{array}$ & $\begin{array}{c}0.451^{* * *} \\
(7.14)\end{array}$ & $\begin{array}{c}0.832^{* * *} \\
(74.1)\end{array}$ & $\begin{array}{c}0.834^{* * *} \\
(73.92)\end{array}$ & $\begin{array}{c}0.827^{* * *} \\
(78.63)\end{array}$ \\
\hline$\Delta \log (\text { LiqAssets })_{t}$ & $\begin{array}{c}0.055^{* * *} \\
(4.48)\end{array}$ & $\begin{array}{c}0.054^{* * *} \\
(4.58)\end{array}$ & $\begin{array}{c}0.055^{* * *} \\
(4.01)\end{array}$ & $\begin{array}{c}0.039 * * * \\
(8.29)\end{array}$ & $\begin{array}{c}0.039 * * * \\
(8.44)\end{array}$ & $\begin{array}{c}0.042^{* * *} \\
(8.89)\end{array}$ \\
\hline Size $_{t}$ & & $\begin{array}{l}0.015 \\
(0.64)\end{array}$ & $\begin{array}{l}0.012 \\
(0.38)\end{array}$ & & $\begin{array}{c}-0.008^{* *} \\
(-2.28)\end{array}$ & $\begin{array}{c}-0.009 * * * \\
(-2.87)\end{array}$ \\
\hline Size $_{t} \cdot \Delta I R_{t-1}$ & & & $\begin{array}{l}-0.004 \\
(-0.76)\end{array}$ & & & $\begin{array}{c}0 \\
(0.06)\end{array}$ \\
\hline cons & $\begin{array}{l}0.017 \\
(1.37)\end{array}$ & $\begin{array}{c}-0.2 \\
(-0.58)\end{array}$ & $\begin{array}{l}0.006 \\
(0.38)\end{array}$ & $\begin{array}{c}-0.026^{* * *} \\
(-17.84)\end{array}$ & $\begin{array}{l}0.074 * \\
(1.69)\end{array}$ & $\begin{array}{c}-0.027 * * * \\
(-18.66)\end{array}$ \\
\hline$A R(1)$ & -5.75 & -5.62 & -5.71 & -14.77 & -14.87 & -14.83 \\
\hline p-val & 0.00 & 0.00 & 0.00 & 0.00 & 0.00 & 0.00 \\
\hline$A R(2)$ & -0.65 & -0.58 & -0.66 & -1.83 & -1.81 & -1.68 \\
\hline p-val & 0.52 & 0.56 & 0.51 & 0.07 & 0.07 & 0.09 \\
\hline No of observation & 7037 & 7037 & 7037 & 12839 & 12839 & 12839 \\
\hline No of banks & 628 & 628 & 628 & 953 & 953 & 953 \\
\hline No of instruments & 171 & 171 & 171 & 149 & 149 & 149 \\
\hline
\end{tabular}

Notes: This table presents the coefficient estimates of loan growth on bank-specific determinants and macroeconomic variables - GMM model results from the program StataSE 13. The bank size in model (6) and (9) is defined as the logarithm of total assets and in model (7) and (10) as deviations from their cross-sectional means. T-statistics are given in parentheses. ${ }^{* *}, * *$ or $*$ next to coefficients indicate that coefficients are significantly different from zero at the $1 \%, 5 \%$, or $10 \%$ levels.

Table 5: Robustness check - full sample and subsample results

\begin{tabular}{|c|c|c|c|c|c|c|c|c|}
\hline & \multicolumn{4}{|c|}{ full sample } & \multicolumn{2}{|c|}{ commercial banks } & \multicolumn{2}{|c|}{ cooperative banks } \\
\hline & OLS & FE & OLS & FE & OLS & FE & OLS & $\mathbf{F E}$ \\
\hline & $2^{\prime}$ & $2^{\prime \prime}$ & $4^{\prime}$ & $4^{\prime \prime}$ & $7^{\prime}$ & $7^{\prime \prime}$ & $10^{\prime}$ & $10^{\prime \prime}$ \\
\hline$\Delta \log (\text { loans })_{\mathrm{t}-1}$ & $\begin{array}{c}0.036 * * * \\
(5.91)\end{array}$ & $\begin{array}{c}-0.035 * * * \\
(-5.35)\end{array}$ & $\begin{array}{c}0.036 * * * \\
(5.92)\end{array}$ & $\begin{array}{c}-0.036 * * * \\
(-5.49)\end{array}$ & $\begin{array}{c}0.033^{* * *} \\
(2.97)\end{array}$ & $\begin{array}{c}-0.044 * * * \\
(-3.76)\end{array}$ & $\begin{array}{c}0.042^{* * *} \\
(9.33)\end{array}$ & $\begin{array}{c}0.018^{* * *} \\
(3.81)\end{array}$ \\
\hline GDPG $_{t-1}$ & $\begin{array}{c}0.009 * * * \\
(12.20)\end{array}$ & $\begin{array}{c}0.009 * * * \\
(11.79)\end{array}$ & $\begin{array}{c}0.009 * * * \\
(11.98)\end{array}$ & $\begin{array}{c}0.009 * * * \\
(11.78)\end{array}$ & $\begin{array}{c}0.015^{* * * *} \\
\quad(8.38)\end{array}$ & $\begin{array}{c}0.019^{* * *} \\
(9.80)\end{array}$ & $\begin{array}{c}0.002^{* * *} \\
(6.79)\end{array}$ & $\begin{array}{c}0.002^{* * *} \\
(6.30)\end{array}$ \\
\hline$\Delta I R_{t-1}$ & $\begin{array}{c}-0.005^{* * *} \\
(-6.20)\end{array}$ & $\begin{array}{c}-0.004 * * * \\
(-4.68)\end{array}$ & $\begin{array}{c}-0.005^{* * *} \\
(-5.36)\end{array}$ & $\begin{array}{c}-0.004 * * * \\
(-4.78)\end{array}$ & $\begin{array}{c}-0.004^{* *} \\
(-2.13)\end{array}$ & $\begin{array}{c}-0.005^{* * *} \\
(-2.72)\end{array}$ & $\begin{array}{l}-0.002 \\
(-1.42)\end{array}$ & $\begin{array}{l}-0.001 \\
(-0.94)\end{array}$ \\
\hline$\Delta \log (\text { Equity })_{\mathrm{t}}$ & $\begin{array}{c}0.574 * * * \\
(62.05)\end{array}$ & $\begin{array}{c}0.558 * * * \\
(58.29)\end{array}$ & $\begin{array}{c}0.574 * * * \\
(62.15)\end{array}$ & $\begin{array}{c}0.556^{* * *} \\
(58.37)\end{array}$ & $\begin{array}{c}0.48 * * * \\
(26.51)\end{array}$ & $\begin{array}{c}0.447^{* * *} \\
(23.7)\end{array}$ & $\begin{array}{c}0.793^{* * *} \\
(166.66)\end{array}$ & $\begin{array}{l}0.79 * * * \\
(160.78)\end{array}$ \\
\hline$\Delta \log \left(\right.$ LiqAssets) ${ }_{\mathrm{t}}$ & $\begin{array}{c}0.075 * * * \\
(18.75)\end{array}$ & $\begin{array}{c}0.069 * * * \\
(17.03)\end{array}$ & $\begin{array}{c}0.074 * * * \\
(18.69)\end{array}$ & $\begin{array}{c}0.067 * * * \\
(16.63)\end{array}$ & $\begin{array}{c}0.074 * * * \\
(10.03)\end{array}$ & $\begin{array}{c}0.068^{* * *} * \\
(9.01)\end{array}$ & $\begin{array}{c}0.045^{* * *} \\
(19.97)\end{array}$ & $\begin{array}{c}0.043^{* * *} * \\
(18.95)\end{array}$ \\
\hline Size $_{t}$ & $\begin{array}{c}0.003^{* * *} \\
\quad(3.15)\end{array}$ & $\begin{array}{c}0.013^{* * *} \\
\quad(3.61)\end{array}$ & $\begin{array}{c}0.004^{* * *} \\
(3.38)\end{array}$ & $\begin{array}{c}0.042 * * * \\
(7.71)\end{array}$ & $\begin{array}{l}-0.002 \\
(-0.83)\end{array}$ & $\begin{array}{c}0.066^{* * *} \\
(6.34)\end{array}$ & $\begin{array}{c}0.000 \\
(-0.07)\end{array}$ & $\begin{array}{l}-0.001 \\
(-0.22)\end{array}$ \\
\hline Size $_{t} \cdot \Delta I R_{t-1}$ & & & $\begin{array}{l}0.000 \\
(0.34)\end{array}$ & $\begin{array}{l}0.000 \\
(0.04)\end{array}$ & $\begin{array}{c}0.000 \\
(-0.03)\end{array}$ & $\begin{array}{c}0.000 \\
(-0.33)\end{array}$ & $\begin{array}{l}0.000 \\
(0.08)\end{array}$ & $\begin{array}{l}0.001 \\
(0.49)\end{array}$ \\
\hline cons & $\begin{array}{c}-0.052 * * * \\
(-3.61)\end{array}$ & $\begin{array}{c}-0.18 * * * \\
(-3.61)\end{array}$ & $\begin{array}{c}-0.007^{* * *} \\
(-3.12)\end{array}$ & $\begin{array}{l}-0.003 \\
(-1.19)\end{array}$ & $\begin{array}{c}0.016 * * * \\
(2.6)\end{array}$ & $\begin{array}{c}0.011^{*} \\
(1.66)\end{array}$ & $\begin{array}{c}-0.027 * * * \\
(-27.61)\end{array}$ & $\begin{array}{c}-0.025 * * * \\
(-25.08)\end{array}$ \\
\hline
\end{tabular}




\begin{tabular}{|c|c|c|c|c|c|c|c|c|}
\hline F-stat & 978.59 & 832.16 & 839.04 & 721.68 & 171.74 & 145.32 & 5466.36 & 5272.33 \\
p-val & 0.00 & 0.00 & 0.00 & 0.00 & 0.00 & 0.00 & 0.00 & 0.00 \\
R-squared & 0.23 & & 0.23 & & 0.15 & & 0.75 & \\
R-sq: within & & 0.21 & & 0.22 & & 0.01 & \\
R-sq: between & & 0.18 & & 0.09 & & 0.08 & 0.61 \\
R-sq: overall & & 0.22 & & 0.18 & & 7037 & 12839 & 12839 \\
No of obs. & 19876 & 19876 & 19876 & 19876 & 7037 & 728 & 953 \\
No of banks & & 1581 & & 1581 & & 628 & \\
\hline
\end{tabular}

Notes: This table presents the coefficient estimates of loan growth on bank - specific determinants and macroeconomic variables - GMM model results from the program StataSE 13. The bank size in model (2') and (2") is defined as the logarithm of total assets and in model $\left(4^{\prime}\right),\left(4^{\prime \prime}\right),\left(7^{\prime}\right),\left(7^{\prime \prime}\right),\left(10^{\prime}\right)$ and $\left(10^{\prime \prime}\right)$ as deviations from their cross-sectional means. T-statistics are given in parentheses. ${ }^{* *},{ }^{* *}$ or ${ }^{*}$ next to coefficients indicate that coefficients are significantly different from zero at the $1 \%, 5 \%$, or $10 \%$ levels.

The model numbers in the table above correspond to the specifications of the models presented above - only the parameter estimation technique has changed.

In order to verify the results of the dynamic panel model, the panel model with fixed effects (FE) and the classical regression model (OLS) was estimated.

Values of the obtained coefficients and directions of dependence do not differ significantly from the results from the GMM model. The survey on the entire sample indicates a positive relationship between GDPG and the dynamics of the volume of loans (the coefficients - also significant - are higher and inform us about a change in loans approximately twice as strong as the previous model indicated $-0.9 \%$ change as a result of $1 \%$ increase GDP). The relationship between the change in interest rates and changes in the volume of loans is also important and in line with expectations. Bank characteristics - changes in equity and liquid assets - are important in the whole sample, similarly to the size of the bank (included as the asset logarithm in 2' and 2" models and as a deviation from the average bank size in the $4^{\prime}$ and 4 " models). It was also confirmed that the size * interest rate interaction was irrelevant in FE and OLS estimation.

The second part of the verification included the study of dependencies in the group of commercial and cooperative banks. The table contains the results - the most important from the perspective of the subject taken - which indicate that the interaction of the size * interest rate in both groups is statistically insignificant. In addition, the ratio at GDPG is considerably lower in the group of cooperative banks compared to commercial banks (similar to the results of the GMM model). Changes in interest rates - both in FE and OLS - cause a reduction in lending in commercial banks. However, in the models for cooperative banks, the changes in lending seem to be independent of changes in the area of interest rates.
On the other hand, changes in the area of own funds are much more significant (the dependence, though significant in both groups of banks, in cooperative banks is about twice as strong). On the other hand, the reverse is true for the significance of changes in the liquidity of assets - the differences visible in the FE and OLS models are even more visible than it was due to GMM.

Particularly noteworthy is the size variable - in cooperative banks it is not important, and in commercial banks the results are ambiguous. Therefore, it seems that the significance of the variable in the general model was related to other characteristics of banks - like the type of activity - strongly correlated with the size of the bank.

The model for cooperative banks has a high R-squared (about 75\%) - as for a model based on increments significant variables included in the model (GDPG, IR changes, equity changes and changes in liquid assets) to a very large extent determine changes in lending in this group of banks.

\section{ConClusions}

The issue of bank lending channel and various characteristics of the banking sector which may have an impact on the effectiveness of transmission of monetary policy, is of interest of economists and scientist, as the matter is widely discussed in appropriate economic literature. In this study, an attempt was made to provide evidence for the impact of size of banks in the sector on the effectiveness of the monetary policy transmission mechanism through the bank lending channel using annual data from 1995-2015 by 1709 commercial and cooperative banks from $27 \mathrm{EU}$ countries. To examine this relationship, the paper employs an econometric model, which takes into account the interaction between the 
variable Interest Rate and the variable Size to verify that the size of the bank strengthens the impact of interest rate changes.

The results generally indicate that there is a positive impact of the bank's size on loan growth (meaning that as the bank size increases, the impact of changes in interest rates in the bank's lending policy is getting smaller and that larger banks are less likely to respond to monetary policy shocks than smaller banks). This result is in line with Kashyap and Stein's (1995) prediction that lending volume of smaller banks is more sensitive to monetary policy changes than that of larger banks. However, interaction between the variables Size and Interest Rate in the model was proved to be irrelevant (a very weak relationship the correlation coefficient amounted only to 0.03 ).
To ponder the issue further, the paper also examined the estimation of analogical models separately in the group of commercial and cooperative banks, obtaining a similar result: the interaction of the variables Size and Interest Rates in both groups of banks is statistically insignificant. However, the results led to a surprising conclusion that in the model (10) we obtained an insignificant factor, i.e. the change in the interest rate is not relevant from the perspective of changes in the volume of loans granted, while in models (8) and (9), the variable was significant, but with a positive sign (which was maybe due to the lack of other variables in the model of variation-specific variability of loans in the group of cooperative banks). This described discrepancy definitely requires further research.

\section{ACKNOWLEDGEMENTS}

We gratefully acknowledge the financial support provided by the Polish National Scientific Centre (NCN) 2016/23/D/HS4/02987. This paper's findings, interpretations, and conclusions are entirely those of the authors and do not necessarily represent the views of institutions at which the authors are affiliated.

\section{REFERENCES}

Ananchotikul, N., Seneviratne, D. (2015). Monetary Policy Transmission in Emerging Asia: The Role of Banks and the Effects of Financial Globalization. IMF Working Paper, WP/15/207.

Blundell, R., Bond, S. (1998). Initial Conditions and Moment Restrictions in Dynamic Panel Data Model.Journal of Econometrics, 87(1), 115-143.

Claessens, S., Ghosh, S., Mihet, R. (2013). Macro-Prudential Policies to Mitigate Financial System Vulnerabilities. Journal of International Money and Finance, 39, 153-185.

De Haan, L. (2001). The Credit Channel in the Netherlands: Evidence from Bank Balance Sheets. European Central Bank Working Paper Series no 98/ December 2001.

De Santis, R.A., Surico P. (2013).Bank Lending and Monetary Transmission in the Euro Area. European Central Bank Working Paper Series no 1568 / July 2013.

Havrylchyk, O., Jurzyk, E. (2005). Does the Bank Lending Channel Work in a Transition Economy? A Case of Poland. European University Viadrina, http://www.ceistorvergata.it/conferenze\&convegni/ banking\&finance/XII_ conference/9DICEMBRE/HavrylchykJurzyk.pdf.

Kashyap, A.K., Stein, J.C. (1995). The Impact of Monetary Policy on Bank Balance Sheets. Carnegie-Rochester Conference Series on Public Policy, 42,151-95.

Matousek, R., Sarantis, N. (2009). The Bank Lending Channel and Monetary Transmission in Central and Eastern European countries. Journal of Comparative Economics, 2009, vol. 37, issue 2, 321-334.

Meral, G. (2015). The Effect of Bank Size and Bank Capital on the Bank Lending Channel for Turkish Banks.American Scientific Research Journal for Engineering, Technology, and Sciences (ASRJETS) (2015) Volume 12, No. 1, 1-28. 